\title{
TERRESTRIAL FILAMENTOUS FUNGI FROM GRUTA DO CATÃO (SÃO DESIDÉRIO, BAHIA, NORTHEASTERN BRAZIL) SHOW HIGH LEVELS OF CELLULOSE DEGRADATION
}

\author{
Caio César Pires de Paula ${ }^{1 *}$, Quimi Vidaurre Montoya ${ }^{2}$, André Rodrigues $^{2}$, Maria Elina Bichuette ${ }^{1}$, \\ and Mirna Helena Regali Seleghim ${ }^{1}$
}

\begin{abstract}
Subterranean environments are oligotrophic. However, few studies have investigated the composition and function of their terrestrial mycobiota. This study examined the functional role of filamentous cave fungi in cellulose degradation. Soil samples and dry sediment were collected in the surface epigean environment and two sites in the entrance and twilight zones inside Gruta do Catão in the São Desidério karst area, state of Bahia, Brazil. Fungi were cultured from the samples, and the total organic carbon, culturable microorganisms, and carbon and nitrogen microbial biomasses were estimated. All fungal strains were evaluated for cellulase production in carboxymethylcellulose synthetic medium, and the enzymatic indices were estimated. We observed a significant difference $(p \leq 0.05)$ in physical, chemical, and biological parameters between epigean soil and cave sediments by Tukey's test. We recovered a total of 20 isolates comprising the genera Aspergillus (50.0\%), Penicillium (25.0\%), Talaromyces (10.0\%), Trichoderma (5.0\%), Purpureocillium (5.0\%) and Scopulariopsis (5.0\%). The majority of the isolates (90\%) showed cellulolytic activity, which is a higher percentage compared to that normally reported in the literature for sediments. Thus there is a high probability that the filamentous fungi act in nutrient cycling, thereby contributing to the quality and maintenance of the cave ecosystem. These results indicate that parameters such as total organic carbon, biomass, and relative humidity that tend to differ between caves and epigean environments, provide selective pressures for microorganisms that use alternative sources of energy and nutrients.
\end{abstract}

\section{INTRODUCTION}

Caves are subterranean environments that are generally considered oligotrophic environments with permanent darkness and a tendency towards environmental constancy in the deep zone (Culver and Pipan, 2009). These conditions provide highly specialized ecological niches for their inhabitants (Culver and Pipan, 2009; Engel et.al., 2001). Little is known about the distribution, population dynamics, and biochemistry of microorganisms in caves (Northup and Lavoie, 2004; Barton and Jurado, 2007), and for Brazil this knowledge is still incipient, according to Vanderwolf et al. (2013), who emphasized a large knowledge gap concerning the diversity of the fungal community in caves worldwide, including Brazilian caves, and highlighted the importance of studies on the distribution of fungal communities and their relationship to subterranean environments. The usage and exploration of subterranean environments for tourism, mining, hydropower, and other purposes often reaches excessive levels, leading to the destruction of habitats. Unfortunately, microbiological studies regarding subterranean microorganisms are neglected and are not considered when establishing parameters for cave exploration. In 2008, the National Center of Study and Conservation of Caves (Centro Nacional de Pesquisa e Conservação de Cavernas, CECAV) published a "term of reference" concerning cave exploration in Brazil that requested studies in several areas, but said little about microbiological studies (CECAV/IBAMA, 2008).

Studies worldwide have reported the extent to which tourism affects the microbial communities in caves (PulidoBosch et al., 1997). Lavoie and Northup (2006) confirmed that the input of organic matter by tourist visits supported the growth of exogenous bacteria and fungi in the subterranean environment. Sensitive indicators that can be used to monitor changes in subterranean environments include enzymatic activity, density, and the biomass of soil bacteria (Kennedy and Papendick, 1995; Matsuoka et al., 2003), because the soil microbiota are mainly responsible for the decomposition of organic wastes and nutrient cycling.

Fungi are dominant among cave microorganisms due to their high rate of dispersion, spore survival, and better capacity for colonization (Wang et al., 2010). Fungi act mainly as decomposers or parasites in caves (Santamaria and Faille, 2007; Yoder et al., 2009) and provide nutrients in

\footnotetext{
* Corresponding Author: piresdepaula@yahoo.com.br

${ }^{1}$ Departamento de Ecologia e Biologia Evolutiva, Universidade Federal de São Carlos, SP

${ }^{2}$ Departamento de Bioquímica e Microbiologia, Universidade Estadual Paulista, Campus Rio Claro, SP
} 
assimilable forms for other organisms. Together with bacteria, fungi are also the main food sources for protozoans and terrestrial invertebrates such as Isopoda crustaceans and Collembolan entognathans (Bichuette and Trajano, 2006). The distribution of fungi along the cave is influenced by the availability of organic matter and microclimatic conditions such as water availability, temperature, and $\mathrm{pH}$ (Vanderwolf et al., 2013).

Although cave-food recycling completely depends on the catabolic and anabolic microbial processes that occur in the absence of light, the input of energy is considered to be insufficient to support the subterranean ecosystem. Some studies that assessed organic matter decomposition in aquatic and marine sediments in caves showed high microbial activity in the early stages of decomposition that correlated with increased microbial respiration (Fishez, 1991; Galas et al., 1996). Other researchers emphasized the importance of the microbial community as key organisms at the base of the subterranean environment food web and in decomposition processes (Pohlman et al., 1997; Graening and Brown, 2003). However, few researchers have studied the involvement of cellulolytic microorganisms in the decomposition process in cave environments (Semikolennykh et al., 1975; KoilRaj et al., 2012). Furthermore, researchers have focused on the cellulose degradation rate or cellulolytic potential of bacterial strains, with no interest in evaluating the role of the fungal community in cellulose decomposition.

The karst area of São Desidério (state of Bahia, northeastern Brazil) has unique characteristics, including a high diversity of troglomorphic organisms showing reduced pigmentation and eye or ocellus, with a wide range of new species to be described (Trajano and Bichuette, 2010; Fernandes et al., 2016). This biodiversity makes knowledge of the subterranean mycobiota highly relevant both for better understanding of specific food webs and for preservation purposes. In an application context, microbiological studies in subterranean environments might lead to the identification of new species (Nováková et al., 2012) that could be of biotechnological interest (Reynolds and Barton, 2014), contribute to knowledge about pathogenic microorganisms, and be useful for the development of protective actions in tourist caves (Porca et al., 2011) and the development of management plans for cave exploration (Nieves-Rivera, 2003; Nieves-Rivera et al., 2009).

This study is the first to focus on the cave mycobiota in the region of São Desidério. We evaluated the involvement of filamentous fungi in cellulose degradation from a subterranean environment to elucidate their role in food webs and ecosystem maintenance, thereby enabling better management of tropical cave environments.

\section{Materials And Methods}

The studied locality was the Gruta do Catão $\left(12^{\circ} 22^{\prime} 6^{\prime \prime} \mathrm{S}\right.$, $44^{\circ} 52^{\prime} 3^{\prime \prime}$ W) located in the Parque Municipal da Lagoa Azul approximately 15 kilometers from São Desidério, Bahia state, Brazil (Fig. 1). The cave is in a 19 hectare part of the João Rodrigues karst system, which is one of most important hydrogeological systems in South America. The cave receives approximately 150 tourists per week. It does not have graffiti and trash, but in the past, the cave was used as a football field. The cave is formed in pure dark-gray limestone from the Proterozoic eon, formed from shallow marine deposits. The weather of São Desidério is tropical, with summer rain. The annual temperature varies between $17.0^{\circ} \mathrm{C}$ and $37.0{ }^{\circ} \mathrm{C}$, and the rainfall reaches $1,700 \mathrm{~mm}$ per year, with well-defined rainy season from November to March (Santos et al., 2008).

Gruta do Catão has two entrance, each about $50 \mathrm{~m}$ wide and $7 \mathrm{~m}$ high, and the length of the cave is approximately 160 $\mathrm{m}$; the area is approximately $15,000 \mathrm{~m}^{2}$. The map of the cave was drawn by the Bambuí Speleological Research Group (Fig. 2). The cave floor is formed by sandy-clay fluvial deposits (dry sediment) that are believed to be the first resurgence of the João Rodrigues subterranean river. The cave does not have an aphotic region, but the brightness of the entrance zone, 100 to 200 lux, and the twilight zone, a maximum of 50 lux, differ from the 500 to 700 lux of the epigean area.

\section{SAMPLING}

The sampling was conducted in October 2012 (Chico Mendes Institute for Biodiversity Conservation (ICMBio/ SISBIO license no. 10215). One quadrant of approximately $0.25 \mathrm{~m}^{2}$ was sampled in three areas (Fig. 2): one in an epigean area (sample 3, outside the cave), one in the entrance zone (sample 1), and one in the twilight zone (sample 2) of the cave. Approximately $300 \mathrm{~g}$ of soil and cave sediment were collected at two different sites in each quadrant. Soil and cave sediment were collected from a depth of 0 to $10 \mathrm{~cm}$ with the aid of a gardening shovel and stored in sterile plastic jars. The samples were transported to the laboratory in coolers, homogenized and sieved ( $2 \mathrm{~mm}$ mesh), and stored in the refrigerator at $4{ }^{\circ} \mathrm{C}$. The shovel and sieve had been disinfected by $2 \mathrm{~min}$ in $70 \%$ alcohol at the site before collecting the substrate. In the laboratory, each sample gave rise to four subsamples, for a total of eight subsamples at each sampled point. The air temperature $\left({ }^{\circ} \mathrm{C}\right)$ and relative humidity $(\%)$ were measured at each sampled area with a minimum time interval of 1 minute between measurements (Thermo-hygrometer Instruntherm THAL-300, 0.1 resolution and $\pm 5.0 \%$ accuracy).

\section{Chemical and Biological Parameters}

Total organic carbon (TOC), microbial carbon and nitrogen biomass ( $\mathrm{MBC}$ and $\mathrm{MBN}$, respectively), and counts of colonyforming unit (CFU) were determined for the soil and cavesediment samples. TOC concentrations were obtained by the method of wet digestion with the oxidation of organic $\mathrm{C}$ with $10 \mathrm{~mL}$ of $0.167 \mathrm{~mol} \mathrm{~L}^{-1} \mathrm{~K}_{2} \mathrm{Cr}_{2} \mathrm{O}_{7}$ (potassium dichromate) and $20 \mathrm{~mL}$ of $\mathrm{H}_{2} \mathrm{SO}_{4}$ (sulfuric acid) (Walkey and Black, 1934).

Journal of Cave and Karst Studies, December 2016 • 209 
Terrestrial filamentous fungi from Gruta do Catão (São Desidério, Bahia, Northeastern Brazil) Show high levels of Cellulose DEGRADATION

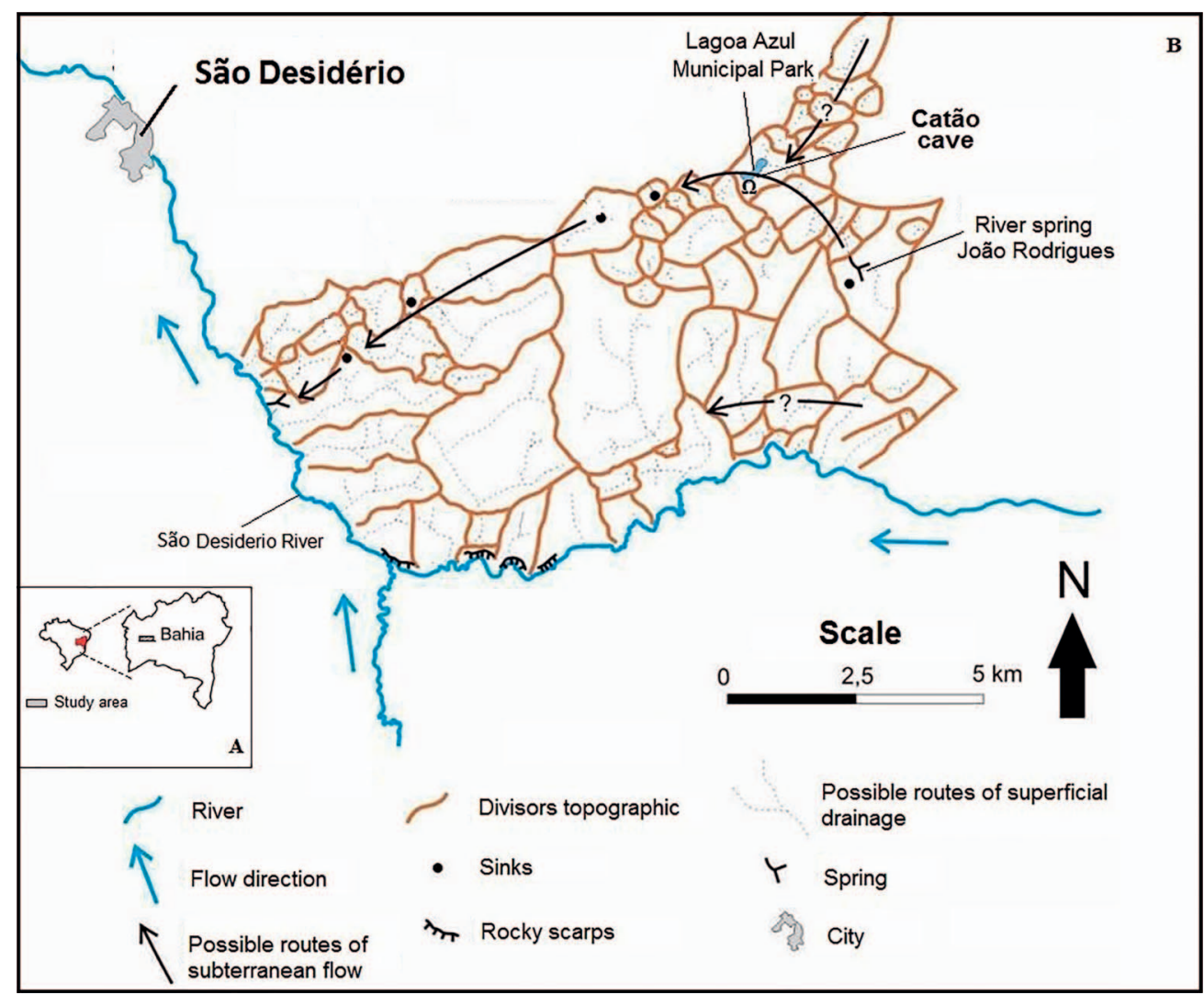

Figure 1. A (inset): Geographical location of São Desidério county. B: João Rodrigues karstic system and the possible route of the subterranean river João Rodrigues (modified from Sá Pereira and Godinho, 2013).

The MBC and MBN were evaluated in $10 \mathrm{~g}$ substrate samples previously adjusted to $40 \%$ moisture content. The MBC was evaluated by the fumigation-extraction method (Vance et al. 1987), and the MBN was evaluated according to the method of Brookes et al. (1985). After this process, a substrate extraction was performed with $0.5 \mathrm{M} \mathrm{K}_{2} \mathrm{SO}_{4}$. The moisture in the soil and cave sediment samples was estimated by the gravimetric method, drying at $105^{\circ} \mathrm{C}$ for $20 \mathrm{~h}$ to 7 days after sampling, and the results were expressed as dry weight. The MBC contents were estimated with a spectrophotometer using the correction factor $\left(\mathrm{K}_{\mathrm{CE}}\right)$ of 0.41 as recommended for tropical soils to avoid overestimating the results (Barbujia et al., 2010). The MBN of the substrate was determined by the addition of $1.5 \mathrm{~mL}$ of $\mathrm{H}_{2} \mathrm{SO}_{4}$ and $50 \mathrm{mg}$ of a catalyst mixture $\left(\mathrm{K}_{2} \mathrm{SO}_{4}+\mathrm{CuSO}_{4}, 10: 1\right)$ to $20 \mathrm{~mL}$ of substrate extract. The $\mathrm{N}$ concentrations were determined by spectrophotometry using the $\mathrm{K}_{\mathrm{NE}}$ correction factor of 0.54 according to Brookes et al. (1985).

The terrestrial culturable bacteria and fungi were determined by the serial dilution method using specific culture medium; the results were expressed as colony-forming units (CFU) per $\mathrm{g}$ of soil. A substrate sample $(5.0 \mathrm{~g}$ in $50 \mathrm{~mL}$ of $0.85 \%$ saline solution) was suspended by shaking at $150 \mathrm{rpm}$ for $30 \mathrm{~min}$ and serially diluted up to $1 / 100,000$ prior to inoculation by spreading onto the solid media. All culture media were prepared in the laboratory by dilution the specific reagents in distilled water: Nutrient agar $\left(5.0 \mathrm{~g} \mathrm{~L}^{-1}\right.$ bacteriological peptone, $3.0 \mathrm{~g} \mathrm{~L}^{-1}$ beef extract, and $15.0 \mathrm{~g}$ $\mathrm{L}^{-1}$ agar, $\mathrm{pH}$ 6.8) was used for total bacteria, and Martin medium $\left(1.0 \mathrm{~g} \mathrm{~L}^{-1} \mathrm{~K}_{2} \mathrm{HPO}_{4}, 0.2 \mathrm{~g} \mathrm{~L}^{-1} \mathrm{MgSO}_{4} \cdot 7 \mathrm{H}_{2} 0,5.0 \mathrm{~g} \mathrm{~L}^{-1}\right.$ soy peptone, $10.0 \mathrm{~g} \mathrm{~L}^{-1}$ glucose, $0.06 \mathrm{~g} \mathrm{~L}^{-1}$ Rose Bengal, and $15.0 \mathrm{~g} \mathrm{~L}^{-1}$ agar, $\mathrm{pH}$ 6.0) was used for total fungi (Wollum II, 1982). The inoculated plates were incubated in the dark at 27 ${ }^{\circ} \mathrm{C}$ and analyzed after 3 days (bacteria) and 7 days (fungi).

\section{Isolation AND Characterization of the FungI}

Fungi were isolated from the plates used for counting. Colonies were inoculated by streaking on Malt agar 3\% (30.0 $\mathrm{g} \mathrm{L}^{-1}$ malt extract, $3.0 \mathrm{~g} \mathrm{~L}^{-1}$ soy peptone, $0.05 \mathrm{~g} \mathrm{~L}^{-1}$ Rose Bengal, and $20.0 \mathrm{~g} \mathrm{~L}^{-1}$ agar, $\mathrm{pH} 5.5$ to 6.0 ) with three replicates per dilution. The samples were incubated for 15 days at $25{ }^{\circ} \mathrm{C}$. On the seventh and fifteenth days, the colonies obtained were isolated by streaking to obtain pure cultures. Each isolated strain was designated SDC x.y, for the study area (São Desidério) and the cave (Gruta do Catão); $x$ is the collection point and $y$ is to the number of the strain.

To ensure the genetic stability of the strains, they were preserved in sterile distilled water and refrigerated at $4{ }^{\circ} \mathrm{C}$ (Castellani, 1939). The characterization of the strains was based on their morphotypes, and the genus identification was 


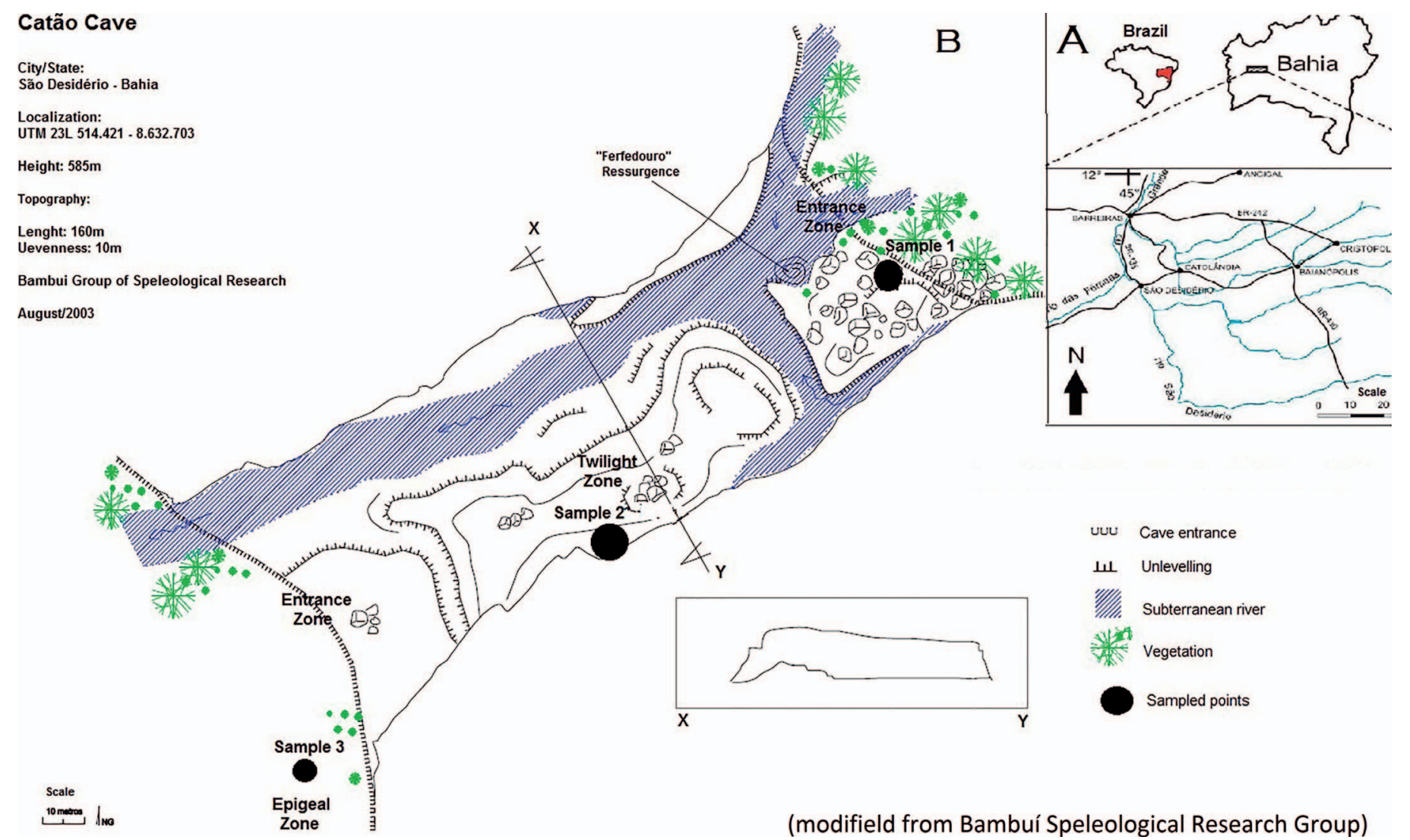

Figure 2. Plan of Gruta de Catão highlighting the entrances and the twilight zone. The three sampling sites are shown.

based on morphological characteristics such as reproductive structures, hyphae, and spores observed by optical stereoscopic and microscopy. Microscopic analyses were made using the microcultive technique with the aid of specialized literature (Barnett and Hunter, 1998).

\section{Production of Cellulolytic Enzymes}

To evaluate the production of cellulolytic enzymes by the isolated strains, the strains were cultivated in synthetic media with carboxymethylcellulose as the only carbon source $(10.0 \mathrm{~g}$ $\mathrm{L}^{-1} \mathrm{CMC}, 10.0 \mathrm{mg} \mathrm{L}^{-1} \mathrm{FeSO}_{4} \cdot 7 \mathrm{H}_{2} \mathrm{O}, 0.5 \mathrm{~g} \mathrm{~L}^{-1} \mathrm{KCl}, 1.0 \mathrm{~g} \mathrm{~L}^{-1}$ $\mathrm{K}_{2} \mathrm{HPO}_{4}, 0.5 \mathrm{~g} \mathrm{~L}^{-1} \mathrm{MgSO}_{4}, 3.0 \mathrm{~g} \mathrm{~L}^{-1} \mathrm{NaNO}_{3}$, and $20.0 \mathrm{~g} \mathrm{~L}^{-1}$ agar, $\mathrm{pH} 5.6$ to 6.0 ). The media were inoculated with the fungal strains using a platinum needle inserted at the center of the Petri dish and incubated for 14 days at $25{ }^{\circ} \mathrm{C}$. On the seventh and fourteenth cultivation days, the formation of a degradation zone was revealed by the addition of $10 \mathrm{~mL}$ of Congo red solution $\left(2.5 \mathrm{~g} \mathrm{~L}^{-1}\right)$ in $0.1 \mathrm{M}$ Tris $\mathrm{HCl}$ buffer $(\mathrm{pH}$ 8.0). The solution was discarded after $30 \mathrm{~min}$, and the cultures were washed with $5 \mathrm{~mL}$ of $0.5 \mathrm{M} \mathrm{NaCl}$ in the same buffer. The halos $\left(\mathrm{D}_{\mathrm{H}}\right)$ and colony diameters $\left(\mathrm{D}_{\mathrm{C}}\right)$ were measured, and the ratios between them were used to estimate the enzyme index $\mathrm{EI}=\mathrm{D}_{\mathrm{H}} / \mathrm{D}_{\mathrm{C}}$. The enzymatic index is a measure of the enzyme activity by radial diffusion in solid medium (Nogueira and Cavalcanti, 1996).

\section{Statistical Analysis}

The chemical and biological variables were submitted for basic descriptive statistics (Shapiro-Wilks). Analysis of variance and Tukey's test with $5 \%$ probability threshold were also applied to verify the significance of the differences among the results. To analyze the influence of the variables on the data, we used principal component analysis in which the main components were greater than or equal to 1 eigenvalue following the Kaiser criterion (McCune et al., 2002). The program PAST version 8.2 (Hammer, 1999) was used for statistical analysis and graphical production.

\section{RESUlts}

Table 1 shows the mean values of the temperature and relative humidity of the air and the moisture content of the soil or dry sediment for the different sampling sites. The mean temperature in the twilight zone of the cavern was $25.1{ }^{\circ} \mathrm{C}$, and the relative humidity of the air was $70.7 \%$ to $75.2 \%$ at the cave sites. The epigean area showed a higher temperature $\left(27.4{ }^{\circ} \mathrm{C}\right)$ and lower relative humidity $(64.3 \%)$. The soil moistures in the epigean area and the sediment in the entrance zone of the cave was higher ( $14.5 \%$ and $10.3 \%$, respectively) compared to the twilight zone $(5.71 \%)$.

Journal of Cave and Karst Studies, December 2016 • 211 
Terrestrial filamentous fungi from Gruta do Catão (São Desidério, Bahia, Northeastern Brazil) Show high levels of Cellulose DEGRADATION

Table 1. Mean values and standard deviations of abiotic parameters (air temperature and relative humidity of air and soil) in the sampling sites.

\begin{tabular}{lccc}
\hline Abiotic Parameters & Epigean Zone & Entrance Zone & Twilight Zone \\
\hline Air temperature $\left({ }^{\circ} \mathrm{C}\right)$ & $27.4 \pm 0.20$ & $25.8 \pm 0.32$ & $25.1 \pm 0.75$ \\
Relative humidity of the air (\%) & $64.3 \pm 0.42$ & $70.7 \pm 0.55$ & $75.2 \pm 1.85$ \\
Moisture content (\%) & $14.5 \pm 0.27$ & $10.3 \pm 0.28$ & $5.71 \pm 0.21$ \\
\hline
\end{tabular}

The total organic carbon values differed among the sampling sites ( $p \leq 0.0028$; Table 2$)$. The epigean area had $2.41 \mathrm{~g} \mathrm{~g} \mathrm{~g}^{-1}$ of carbon in the soil on average, whereas the entrance and twilight Zones showed mean values of $1.3 \mathrm{~g} \mathrm{~g}^{-1}$ and $0.49 \mathrm{~g} \mathrm{~g}^{-1}$ of sediment, respectively. The highest $\mathrm{C}$ and $\mathrm{N}$ microbial biomasses were found in the epigean area and the lowest in the twilight zone. The MBC ranged from $59.9 \mathrm{mg}$ $\mathrm{g}^{-1}$ of sediment in the twilight zone to $1428.1 \mathrm{mg} \mathrm{g}^{-1}$ of soil in the epigean are, with significant differences between all three sampled sites $(p \leq 0.0001)$. The amount of the $\mathrm{N}$ microbial biomass was also significantly different among the three sampled sites $(p \leq 0.0020)$, with values ranging between 0.51 $\mathrm{mg} \mathrm{g}^{-1}$ of sediment in the twilight zone and $6.5 \mathrm{mg} \mathrm{g}^{-1}$ of soil in the epigean area.

The epigean environment had higher amounts of culturable bacteria compared to the other sites in the cave $(p \leq 0.0010$; Table 2). However, there was no significant difference between the values found for the sites inside the cave ( $p=$ $0.6080)$. There was no significant difference in culturable fungi among the three sampled sites $(p \geq 0.8070)$, but the epigean area showed a greater coefficient of variation of their averages compared with the subterranean environment $\left(\mathrm{CV}_{\mathrm{Epg}}\right.$ =66.9; $\left.\mathrm{CV}_{\mathrm{EZ}}=35.2 ; \mathrm{CV}_{\mathrm{TZ}}=37.4\right)$.

The principal-component analysis aims to summarize a large number of variables in two dimensions. The principle components represent the eigenvalues, with the component 1 representing the largest variance of the data, and the component 2 representing the second largest variance of the data. The principal-component analysis of the variables (Fig. 3 ) revealed that the culturable fungi explained the majority of the data variance $(76.2 \%)$. Figure 3 shows that the points for the subsamples in the epigean area (Epg) were more dispersed compared with the other sites, indicating that the heterogeneity of the soil at this location was higher compared to the other sites. The points representing the data from the entrance zone (EZ) and twilight zone (TZ) were closer to one another and the
TZ points were the most clustered, demonstrating greater uniformity of the data.

Only the isolates from the entrance and twilight-zone samples were identified and evaluated for production of cellulolytic enzymes because the aim of the study was to evaluate the role of the fungal community of the subterranean environment on cellulose degradation. A total of twenty fungal morphotypes were isolated, including seven from the entrance zone and 13 from the twilight zone (Table 3). The strains were identified in the following genera: Aspergillus (50.0\%), Penicillium (25.0\%), Talaromyces (10.0\%), Trichoderma (5.0\%), Purpureocillium (5.0\%) and Scopulariopsis (5.0\%).

The strains isolated from the cave entrance and twilight zones were evaluated for the production of cellulolytic enzymes. Figure 4 shows the enzyme indices obtained after fungal cultivation on synthetic media. The halo indicating the degradation of carboxymethylcellulose was observed in 18 of the examined strains (90\%). The highest enzyme indices were found for the following strains: Penicillium SDC 2.13, IE 2.40, Scopulariopsis SDC 2.1, IE 2.46, and Talaromyces SDC 2.9, IE 2.48. All of the strains, with the exception of Aspergillus sp 4 (section Nigri) and Trichoderma, which did not produce degradation halos, showed a higher enzyme index on the seventh cultivation day compared to the fourteenth.

\section{DiscusSION}

Analyses of the physical abiotic variables revealed that they were significantly different between sampling locations. The largest amount of total organic carbon was observed in the epigean area, as expected, because this location had a greater richness of carbon sources. The input of organic carbon into the subterranean environment occurs through two main pathways: small openings, cracks, and sinks that allow the entry of leaves, wood, and debris from streams and epikarstic environments (Simon et al., 2007), or carbon

Table 2. Total organic carbon (TOC), microbial biomass carbon (MBC), microbial biomass nitrogen (MBN), culturable bacteria and fungi estimated for the soil and sediment of the Gruta do Catão in the Epigean area, Entrance Zone and Twilight Zone.

\begin{tabular}{lccccc}
\hline Sampled Sites & $\begin{array}{c}\text { TOC } \\
\left(\mathrm{g} \mathrm{g}^{-1} \text { soil }\right)\end{array}$ & $\begin{array}{c}\text { MBC } \\
\left(\mathrm{mg} \mathrm{g}^{-1} \text { soil }\right)\end{array}$ & $\begin{array}{c}\text { MBN } \\
\left(\mathrm{mg} \mathrm{g}^{-1} \text { soil }\right)\end{array}$ & $\begin{array}{c}\text { Bacteria } \\
\mathrm{CFU} \mathrm{g}^{-1} \text { soil }\end{array}$ & $\begin{array}{c}\text { Fungi } \\
\mathrm{CFU} \mathrm{g}^{-1} \text { soil }\end{array}$ \\
\hline Epigean area & $2.41^{*}$ & $1428.1^{*}$ & $6.64^{*}$ & $1.810^{6 *}$ & $3.010^{5 *}$ \\
Entrance Zone & $1.30^{* *}$ & $146.18^{* *}$ & $1.74^{* *}$ & $1.0210^{6 * *}$ & $2.5710^{5 *}$ \\
Twilight Zone & $0.49^{* * *}$ & $59.95^{* * *}$ & $0.52^{* * *}$ & $9.010^{5 * *}$ & $2.710^{5 *}$ \\
\hline
\end{tabular}

Note: Values with different numbers of asterisks in a column differ between sites with significance $(p<0.05)$. 


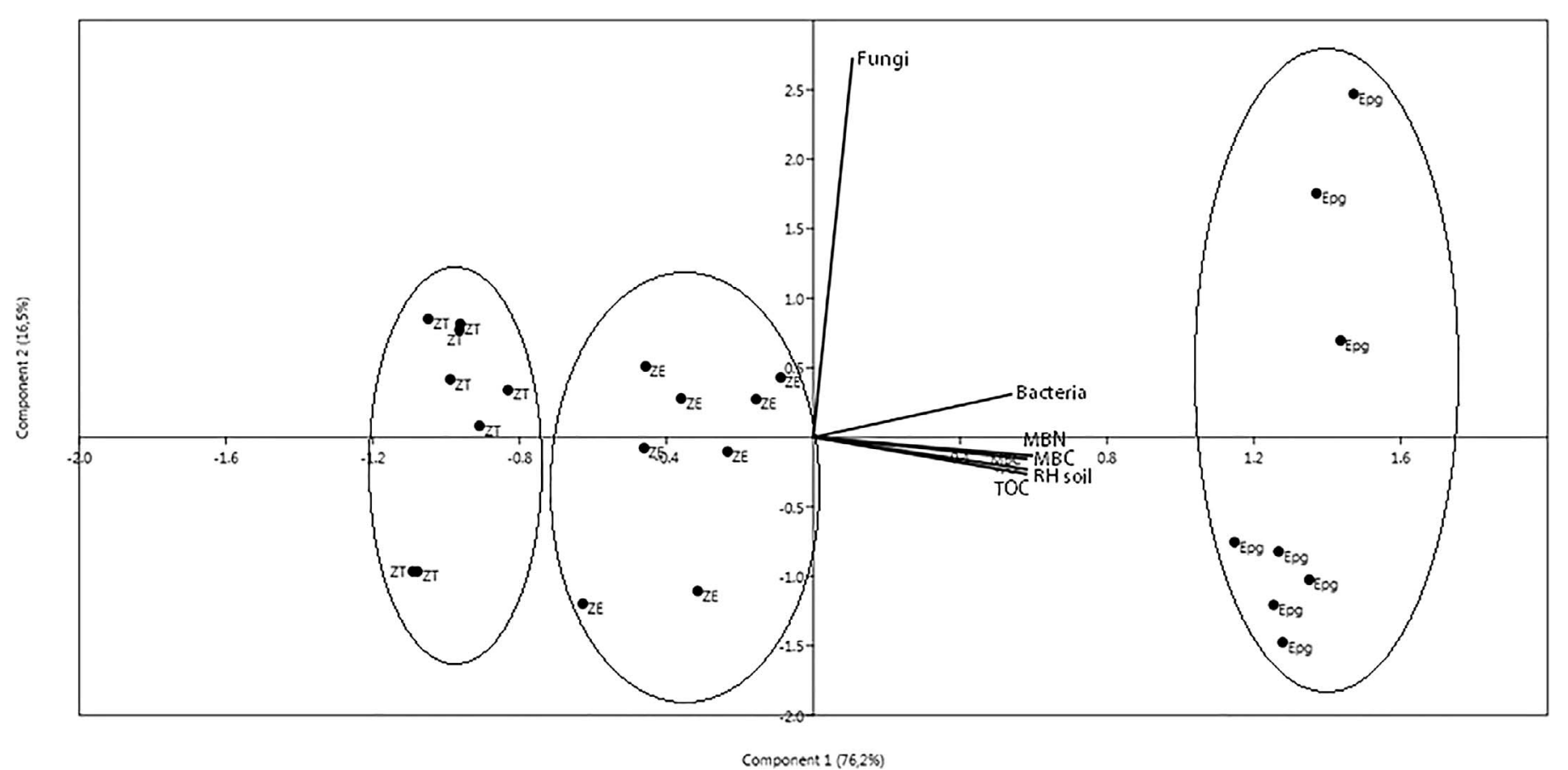

Figure 3. Principal component analysis highlighting the variables (total organic carbon (TOC), microbial biomass carbon (MBC), microbial biomass nitrogen (MBN), total organic carbon, and culturable bacteria and fungi) that had greatest effect on the distributions of the data from the subsamples of each sample site $(E p g=$ epigean area; $E Z=$ entrance zone; $\mathrm{TZ}=$ twilight zone). The vectors represent the weight of each variable on the variance of the data.

particles brought by animals that enter and leave the caves (Graening and Brown, 2003) or visiting sightseers.

The epigean area also had higher microbial biomass values compared to the internal sites in the cave. According to Matsuoka et al. (2003), the diversity of vegetation and its presence all year in the Epigean areas influence the yield and quality of leaf litter, thereby contributing to higher levels of microbial biomass. According to Lavoie and Northup (2006), D.J. Feldhake observed that the organic matter and microbial biomass content were lower in sediments from North American caves compared to forest soils. Moreover, recent research using molecular methods showed higher values for microbial biomass on the surface than inside Kartchner Caverns, USA (Ortiz et al., 2013; Ortiz et al., 2014).

The significant difference in the concentration of bacteria, based on colony-forming units, between the epigean zone and the cave sites can be explained by the smaller organic content available inside the cave. Similar studies have shown this

Table 3. Terrestrial fungi isolated from the Entrance and Twilight Zone of Gruta do Catão.

\begin{tabular}{|c|c|c|c|}
\hline \multicolumn{2}{|c|}{ Entrance Zone } & \multicolumn{2}{|c|}{ Twilight Zone } \\
\hline Code & Identification & Code & Identification \\
\hline SDC 1.1 & Aspergillus sp.3 & SDC 2.1 & Scopulariopsis \\
\hline SDS 1.2 & Aspergillus sp.5 & SDC 2.2 & Talaromyces \\
\hline SDC 1.3 & Penicillium sp. 1 & SDC 2.3 & Trichoderma \\
\hline SDC 1.4 & Aspergillus sp.6 & SDC 2.4 & Aspergillus sp.1 \\
\hline SDC 1.5 & Penicillium $\mathrm{sp} .2$ & SDC 2.5 & Purpureocillium \\
\hline SDC 1.6 & Aspergillus sp.4 (section Nigri) & SDC 2.6 & Aspergillus sp.5 \\
\hline \multirow{7}{*}{ SDC 1.7} & Penicillium sp.3 & SDC 2.7 & Penicillium sp.2 \\
\hline & & SDC 2.8 & Aspergillus sp.8 \\
\hline & & SDC 2.9 & Penicillium sp. 3 \\
\hline & & SDC 2.10 & Aspergillus sp.9 (section Flavi) \\
\hline & & SDC 2.11 & Aspergillus sp.2 \\
\hline & & SDC 2.12 & Aspergillus sp.7 \\
\hline & & SDC 2.13 & Penicillium sp.4 \\
\hline
\end{tabular}


Terrestrial filamentous fungi from Gruta do Catão (São Desidério, Bahia, Northeastern Brazil) Show high levels of Cellulose DEGRADATION

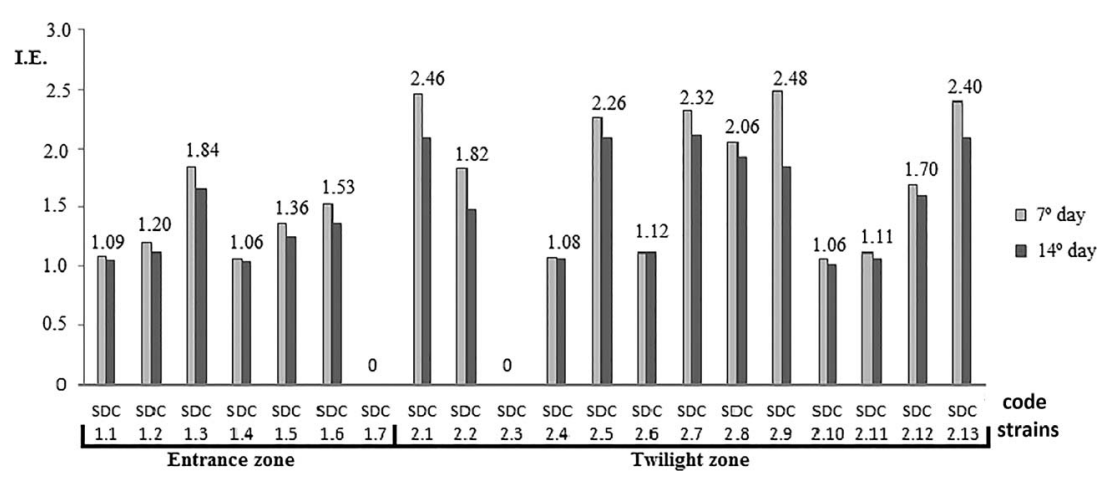

Figure 4. Enzymatic index (IE) of the filamentous fungi strains isolated from the sediment in Gruta do Catão and cultivated in synthetic media with carboxymethylcellulose for 7 and 14 days at $25{ }^{\circ} \mathrm{C}\left(\mathrm{IE}=\mathrm{D}_{\mathrm{H}} / \mathrm{D}_{\mathrm{C}}\right.$, where $\mathrm{D}_{\mathrm{H}}$ is the halo diameter and $\mathrm{D}_{\mathrm{C}}$ is the colony diameter). The horizontal labels are the strain numbers in Table 3.

same pattern in caves, but KoilRaj et al. (2012) found a greater range in bacterial density in soils $\left(2.1 \times 10\right.$ to $3.7 \times 10^{5} \mathrm{CFU}$ $\mathrm{g}^{-1}$ soil) in four Indian caves. There were no significant differences in the culturable fungi among the sampling sites, although the culturable fungi in the epigean area showed greater variation compared to the sampled sites inside the cave. The culturable fungi reported in a study conducted by KoilRaj et al. (2012) were lower compared to our study, ranging between $1 \times 10^{4}$ and $1.9 \times 10^{5} \mathrm{CFU} \mathrm{g}^{-1}$ soil.

According to the principal component analysis of the variables (Fig. 3), the sites in the epigean area and the entrance and twilight zones fall in different and well-defined clusters. The points representing data from the epigean were more dispersed in comparison with the other sites; the clusters for the cave zones were closer to one another, and the points of twilight zone were the most tightly clustered. Soil is a heterogeneous environment consisting of a mosaic of microhabitats, and in an epigean area there is well-conserved native vegetation. Therefore, the complexity and the nutrient resources in epigean soil produce a greater heterogeneity of microhabitats relative to the sediment inside the cave that directly influences a greater variability in fungal density in our subsamples. The entrance zone of the cave is a transition area between two distinct ecosystems and contains a greater variety of niches and substrates compared to the twilight zone.

The number of fungal isolates was relatively low compared with the data obtained by other authors studying Atlantic Forest and Tropical Forest soil ecosystems, who isolated 80 to 110 strains (Ruegger and Tauk-Tornisiselo, 2004; Delabona et al., 2012). Our low numbers of strains were probably due to selection favoring only some strains. Some species of fungi require light to induce sporulation and metabolic activity (Tisch and Schmoll, 2010), and these species will have more difficulty surviving in the cave environment. The input of microorganisms by dripping water and periodic flooding of the river may carry organisms that cannot survive the cave conditions and are used by opportunistic fungi as a source of nutrients. Use of a nutrient-rich medium for the isolation of fungi may have restricted the growth of strains that are better adapted to oligotrophic conditions (Tomova et al., 2013). We observed that the number of isolates was higher in the samples deeper inside the cave compared to the entrance zone. Periods of flooding in caves can be considered a natural control of the diversity and distribution of fungi in the soil, and the subterranean environment takes two to three months to recover a community close to the original composition (Shacklette and Hasenclever, 1968; Vanderwolf et al., 2013). Thus the lower number of isolates in the entrance zone at Gruta do Catão can be explained by the fact that this site is more susceptible to flood pulses, being closer to the stream.

The genera obtained in this work are most commonly isolated in cave environments, both in Brazil (Casirillión et al., 1976, Taylor et al., 2013) and worldwide (Nieves-Rivera, 2003; Nieves-Rivera et al., 2009; Nováková et al., 2012; Vanderwolf et al., 2013). Taylor et al. (2013) obtained the same genera as the most abundant and in similar proportions at Gruta Lapa Nova, Brazil. Contrary to the observations in our study, other researchers obtained a greater diversity of genera in studies of subterranean environments (NievesRivera et al., 2009). A comparison with other studies on cave microbiota is difficult, because these studies are scarce and use different approaches, such as focusing on identifying Basidiomycetes (Pedro and Bononi, 2007) and fungi associated with invertebrates (McCarthy et al., 2011).

Despite the genera being common, the analysis of their cellulolytic enzyme production revealed that $90 \%$ of the isolates produced cellulases (18 strains). In the study by Ruegger and Tauk-Tornisiselo (2004), only $45 \%$ of the strains isolated from the soil of the Atlantic Forest exhibited a degradation halo. Therefore, the percentage of isolated strains producing cellulases was higher in comparison with other studies. Because subterranean rivers contain dissolved organic carbon, particulate organic matter, and biopolymers such as cellulose introduced from the surface soil by percolating water (Culver and Pipan, 2009), we may conclude that the periodic flooding of the subterranean Rio João Rodrigues in the Gruta do Catão causes a discharge of nutrients and carbon into the 
sediment of this cave. Moreover, during rainy periods a large amount of organic matter, mainly plant residues, from the surface is washed down by flooding into the subterranean cavities.

Fungi are the main agents involved in cellulose decomposition at the soil surface (Griffin, 1985; Jennings, 1987), although copiotrophic bacteria dominate the early stages by consuming simple carbohydrate chains such as glucose. Cellulolytic enzymes in fungi are activated following the decrease in bacterial biomass caused by the depletion of these carbohydrates, thereby enabling the fungi to dominate the remainder of the cellulose-waste decomposition process $(\mathrm{Hu}$ and van Bruggen, 1997). Other factors also enable fungi to be more successful than other microorganisms in cellulose decomposition, such as their growth in the hyphal and mycelium forms. This characteristic enables them to cross soil with poor nutrients in the search of resources that are distributed unevenly in the environment and penetrate plant tissues to release cellulolytic enzyme complexes (de Boer et al., 2005).

The results of this study indicate that the majority of filamentous fungi isolated from this subterranean environment are able to produce enzymes that hydrolyze cellulose. Thus, based on the high percentage of cellulolytic fungi found in this study, we can infer that they may play a fundamental role in the subterranean environment. The fungi may function in the decomposition of the organic waste and nutrients and make them available to other organisms in assimilable forms, in addition to serving as an important source of food for some organisms at the base of the food chain (Cubbon, 1976, Poulson and Lavoie, 2000). Therefore, we can infer that cellulolytic hydrolysis may be an important pathway for energy flow and carbon in subterranean ecosystems.

Studies monitoring the fungal community composition and distribution during a hydrological cycle in a karst area would contribute to our understanding of the mycological and functional diversity of terrestrial mycobiota communities and their distribution patterns in the subterranean environment. With our information and knowing the times of higher or lower abundances, we could predict changes in the abundance of the fungal community during periods with increased tourist flow and reduce the negative impact of this activity on cave biodiversity. Moreover, research is needed in subsurface environments with different lithologies in Brazil to enable better assessment of the ecological processes and to preserve these ecosystems, thereby allowing better comparisons among the environments and a more robust assessment of the importance of each cavity.

\section{Conclusion}

The dry sediment of the subterranean environment in this study is different from the epigean soil in most of the examined chemical and biological parameters. These differences provide unique niches in the subterranean environment for organisms and the fungal community. A diversity of fungal genera commonly isolated from similar environments were found in the cave sediment. Ninety percent of the strains exhibited cellulase production, indicating that this environment favored the development and propagation of fungi that possess alternative and more complex mechanisms to obtain energy and nutrients. This high proportion of cellulolytic fungal isolates suggests that they are important organisms for nutrient cycling, thereby contributing to the quality and maintenance of the cave ecosystem. The flood periods can be considered as a natural phenomenon that control the diversity and distribution of the fungi in the soil, so the monitoring of their density, richness, and enzymatic activity along the cave is important before and after these floods. Future management plans should include more detailed microbiological studies to better understand the relationship between the microbiota and Gruta do Catão's ecosystem and to allow better management of parks and protected areas.

\section{ACKNOWLEDGEMENTS}

The authors are grateful to the team of the Laboratório de Estudos Subterrâneos of the Federal University of São Carlos (Camile Sorbo Fernandes, Jonas Eduardo Gallão, Luiza Bertelli Simões, and Diego Monteiro von Schimonsky) for undertaking the sampling in the field and Darci C.D. Javaroti for assistance in the laboratory work. We thank the São Paulo Research Foundation (FAPESP 2010/08459-4) for the financial support and M.E.B. (coordinator). We also thank the Post-Graduate Program in Ecology and Natural Resources, UFSCar (PPGERN), for the infrastructure and the Coordination of Improvement of Higher Education (CAPES) for the scholarship to Caio César Pires de Paula.

\section{REFERENCES}

Barbujia, L.C., Hungria, M., Franchini J.C., and Brookes P.C., 2010, Microbial biomass and activity at various soil depths in a Brazilian oxisol after two decades of no-tillage and conventional tillage: Soil Biology and Biochemistry, v. 42, p. 2174-2181. doi:10.1016/j.soilbio.2010.08.013.

Barnett, H.L., and Hunter, B.B., 1998, Illustrated Genera of Imperfect Fungi fourth edition: St. Paul, MN, American Phytopathological Society Press, $217 \mathrm{p}$.

Barton, H.A., and Jurado, V., 2007, What's up down there? Microbial diversity in caves: Microbe Magazine, v. 2, no. 3, p. 132-138.

Bichuette, M.E., and Trajano, E., 2006, Morphology and distribution of the cave knifefish Eigenmannia vicentespelaea Triques, 1996 (Gymnotiformes: Sternopygidae) from Central Brazil, with an expanded diagnosis and comments on subterranean evolution: Neotropical Ichthyology, v. 4, no. 1, p. 99-105. doi:10.1590/S1679-62252006000100011.

de Boer, W., Folman, L.B., Summerbell, R.C., and Boddy, L., 2005, Living in a fungal world: impact of fungi on soil bacterial niche development: FEMS Microbiology Reviews, v. 29, no. 4, p. 795-811. doi:10.1016/j. femsre.2004.11.005.

Brookes, P.C., Landman, A., Pruden, G., and Jenkinson, D.S., 1985, Chloroform fumigation and the release of soil nitrogen: a rapid direct extraction method to measure microbial biomass nitrogen in soil: Soil Biology and Biochemistry, v. 17, p. 837-842. doi:10.1016/ 0038-0717(85)90144-0. 
Casirillión, A.L., Moraes, M.A.P, and Furtado, M.S.S., 1976, Isolamento de Microsporum amazonicum do solo do estado do Amazonas, Brasil: Acta Amazônica, v. 6, no. 4, p. 487-490.

Castellani, A., 1939, Viability of some pathogenic fungi in distilled water: American Journal of Tropical Medicine and Hygiene, v. 42, p. 225-226.

CECAV/IBAMA, 2008, Termo de referência: estudos específicos de espeleologia para a elaboração de planos de manejos em unidades de conservação que permitam a utilização das cavidades para fins turísticos: Brasília, Centro Nacional de Estudos, Proteção e Manejo de Cavernas.

Cubbon, B.D., 1976, Cave flora, in Ford, T.D., and Cullingford, C.H.D., ed., The Science of Speleology: London, Academic, p. 423-452.

Culver, D.C., and Pipan, T., 2009, The Biology of Caves and Other Subterranean Habitats: Oxford University Press. 254 p.

Delabona, P.S., Pirota, R.D., Codima, C.A., Tremacoldi, C.R., Rodrigues, A., and Farinas, C.S., 2012, Using Amazon forest fungi and agricultural residues as a strategy to produce cellulolytic enzymes: Biomass Bioenergy, v. 37, p. 243-250. doi:10.1016/j.biombioe.2011.12.006.

Engel, A.S., Porter, M.L., Kinkle, B.K., and Kane, T.C., 2001, Ecological assessment and geological significance of microbial communities from Cesspool Cave, Virginia: Geomicrobiology Journal, v. 18, p. 259-274. doi:10.1080/01490450152467787.

Fernandes, C.S., Batalha, M.A., and Bichuette, M.E., 2016, Does the cave environment reduce functional diversity?: PloS one, v. 11, no. 3, p. e0151958. doi.org/10.1371/journal.pone.0151958.

Fichez, R., 1991, Composition and fate of organic-matter in submarine cave sediments; implications for the biogeochemical cycle of organic-carbon: Oceanologica Acta, v. 14 , no. 4, p. 369-377.

Galas, J., Bednarz, T., Dumnicka, E., Starzecka, A., and Wojtan, K., 1996, Litter decomposition in a mountain cave water: Archiv für Hydrobiologie, v. 138 , no. 2 , p. $199-211$

Graening, G.O., and Brown, A.V., 2003, Ecosystem dynamics and pollution effects in an Ozark cave stream: Journal of the American Water Resources Association, v. 39, p. 1497-1505. doi:10.1111/j.1752-1688.2003.tb04434.x.

Griffin, D.M., 1985, A comparison of the roles of bacteria and fungi, in Leadbetter, E.R., and Poindexter, J.S., eds., Bacteria in Nature. Volume 1. Bacterial Activities in Perspective: New York, Plenum, p. 221-255.

Hammer, Ø., 1999, Paleontological Statistics: Natural History Museum, University of Oslo, $187 \mathrm{p}$.

$\mathrm{Hu}, \mathrm{S}$., and van Bruggen, A.H.C., 1997, Microbial dynamics associated with multiphasic decomposition of ${ }^{14} \mathrm{C}$-labeled cellulose in soil: Microbial Ecology, v. 33, no. 2, p. 134-143. doi:10.1007/s002489900015

Jennings, D.H., 1987, Translocation of solutes in fungi: Biological Reviews, v. 62, p. 215-243. doi:10.1111/j.1469-185X.1987.tb00664.X.

Kennedy, A.C., and Papendick, R.I., 1995, Microbial characteristics of soil quality: Journal of Soil and Water Conservation, v. 50, no. 3, p. 243-248

KoilRaj, A.J., Prabhavathi, P., Rajendran, R., Kuberan, T., Gowri, R.S., and Selvi, C.P., 2012, Degradation of organic wastes and recycling of nutrients enhanced by microbes in subterranean habitat: African Journal of Microbiology Research, v. 6, no. 21, p. 4449-4456. doi:10.5897/ AJMR11.239.

Lavoie, K.H., and Northup, D.E., 2006, Bacteria as indicators of human impact in cave, in Rea, G.T., ed., Proceedings of the 2005 National Cave and Karst Management Symposium: NCKMS Steering Committee [no place given], p. 40-47.

Matsuoka, M., Mendes, I.C., and Loureiro, M.F., 2003, Biomassa microbiana e atividade enzimática em solos sob vegetação nativa e sistemas agrícolas anuais e perenes na região de Primavera do Leste (MT): Revista Brasileira de Ciência do Solo, v. 27, p. 425-433. doi:10.1590/ S0100-06832003000300004.

McCarthy, C.B., Diambra, L.A., and Rivera Pomar, R.V.R., 2011, Metagenomic analysis of taxa associated with Lutzomia longipalpis, vector of visceral Leischimaniosis, using an unbased high-throughput approach: PLOS Neglected Tropical Diseases, v. 5, no. 9, art. 1304, 10 p. doi:10.1371/journal.pntd.0001304.

McCune, J., Grace, J.B., and Urban, D.L., 2002, Analysis of Ecological Communities: Gleneden Beach, Oregon, MjM Software Design, 304 p.

Nieves-Rivera, Á.M., 2003, Mycological survey of Río Camuy Caves Park, Puerto Rico: Journal of Cave and Karst Studies, v. 65, no. 1, p. 23-28.

Nieves-Rivera, Á.M., Santos-Flores, C.J., Dugan, F.M., and Miller, T.E., 2009, Guanophilic fungi in three caves of southwestern Puerto Rico International Journal of Speleology, v. 38, no. 1, p. 61-70. doi:10.5038/ 1827-806X.38.1.7

Nogueira, E.B.S., and Cavalcanti, M.A.Q., 1996, Cellulolytic fungi isolated from processed oats: Revista de Microbiologia, v. 27, p. 7-9.
Northup, D.E., and Lavoie, K.H., 2004, Microbiology in caves, in Gunn, J., 2004, Encyclopedia of Cave and Karst Science: New York, Fitzroy Dearborn Publishers, p. 506-509.

Nováková, A., Hubka, V., Saiz-Jimenez, C., and Kolarik, M., 2012, Aspergillus baeticus sp. nov. and Aspergillus thesauricus sp. nov., two species in section Usti from Spanish caves: International Journal of Systematic and Evolutionary Microbiology, v. 62, p. 2778-2785. doi:10. 1099/ijs.0.041004-0.

Ortiz, M., Neilson, J.W., Nelson, W.M., Legatzki, A., Byrne, A., Yu, Yeisoo, Wing, R.A., Soderlund., C.A., Pryor, B.M., Pierson III., L.S., and Maier, R.M., 2013, Profiling bacterial diversity and taxonomic composition on speleothem surfaces in Kartchner Caverns, AZ: Microbial Ecology, v. 65, p. 371-383. doi:10.1007/s00248-012-0143-6.

Ortiz., M., Legatzki., A., Neilson., J.W., Fryslie., B., Nelson., W.M., Wing., R.A., Soderlund., C.A., Pryor., B.M., Maier., R.M., 2014, Making a living while starving in the dark: metagenomic insights into the energy dynamics of a carbonate cave: ISME Journal, v. 8, no. 2, p. 478-491. doi:10.1038/ ismej.2013.159.

Pedro, E.G., and Bononi, V.L.R., 2007, Cave fungi of the karst region of the State Touristic Park of the Upper Ribeira Valley (PETAR) in the State of São Paulo in Brazil: Focus, v. 5, p. 65-78.

Pohlman, J.W., Iliffe, T.M., and Cifuentes, L.A., 1997, A stable isotope study of organic cycling and the ecology of an anchialine cave ecosystem: Marine Ecology Progress Series, v. 155, p. 17-27.

Porca, E., Jurado, V., Martin-Sanchez, P.M., Hermosin, B., Bastian, F., Alabouvette, C., and Saiz-Jimenez, C., 2011, Aerobiology: An ecological indicator for early detection and control of fungal outbreaks in caves: Ecological Indicators, v. 11, p. 1594-1598. doi:10.1016/j.ecolind.2011.04. 003 .

Poulson, T.L., and Lavoie, K.H., 2000, The trophic basis of subsurface ecosystems, in Wilkens, H., Culver, D.C., and Humphreys, W.F., eds., Subterranean Ecosystems, Amsterdam, Elsevier, Ecosystems of the World 30, p. 231-249.

Pulido-Bosch, A., Martín-Rosales, W., López-Chicano, M., RodríguezNavarro, C.M., and Vallejos, A., 1997, Human impact in a tourist karstic cave (Araceña, Spain): Environmental Geology, v. 31, no. 3-4, p. 142-149. doi: $10.1007 / \mathrm{s} 002540050173$.

Reynolds, H.T., and Barton, H.A., 2014, Comparison of the white-nose syndrome agent Pseudogymnoascus destructans to cave-dwelling relatives suggests reduced saprotrophic enzyme activity: PLOS ONE, v. 9, no. 1, art. 86437,11 p. doi:10.1371/journal.pone.0086437.

Ruegger, M.J.S., and Tauk-Tornisiselo, S.M., 2004, Atividade da celulase de fungos isolados do solo da Estação Ecológica de Juréia-Itatins, São Paulo, Brasil: Revista Brasileira de Botânica, v. 27, no. 2, p. 205-211.

Sá Pereira, L.P., and Godinho, R.G.F.A., 2013, Caracterização morfológica preliminar do sistema cárstico do rio João Rodrigues, São Desidério - BA, in Rasteiro, M.A., and Morato, L., eds., Anais $32^{\circ}$ Congresso Brasileiro de Espeleologia, p. 341-351.

Santamaria, S., and Faille, A., 2007, Rhachomyces (Ascomycota, Laboulbeniales) parasites on cave inhabiting Carabid beetles from the Pyrenees: Nova Hedwigia, v. 85, p. 159-186. doi:10.1127/0029-5035/2007/ 0085-0159.

Santos, A.B., Carvalho, A.R., Nunes Junior, D.S., Nunes, G.S., Souza, O.R., Filho, J.N., Menezes, J., Novaes, Z.L.R, 2008, Plano ambiental para o município de São Desidério, BA. Programa Nacional de Capacitação de Gestores Ambientais, Salvador, BA.

Semikolennykh, A.A., Ivanova, A.E., Dobrovolskaja, T.G., and Gorlenko, M.V., 1975, Soil and gypsum caves microbial communities of karstogenic landscapes of Archangelsk Region (Russia), in Petreas, C., ed., Proceedings of the 14th International Congress of Speleology: Athens, Hellenic Speleological Society, p. 642-646.

Shacklette, M.H., and Hasenclever, H.F., 1968, The natural occurrence of Histoplasma capsulatum in a cave. 3. Effect of flooding: American Journal of Epidemiology, v. 88, no. 2, p. 210-214.

Simon, K.S., Pipan, T., and Culver, D.C., 2007, Conceptual model of the flow and distribution of organic carbon in caves: Journal of Cave and Karst Studies, v. 69 , no. 2, p. 279-284.

Taylor, E.L.S., Stoianoff, M.A.R., and Ferreira, R.L., 2013, Mycological study for a management plan of a neotropical show cave (Brazil): International Journal of Speleology, v. 42, no. 3, p. 267-277. doi:10.5038/1827-806X. 42.3.10.

Tisch, D., and Schmoll, M., 2010, Light regulation of metabolic pathways in fungi: Applied Microbiology and Biotechnology, v. 85, p. 1259-1277. doi:10.1007/s00253-009-2320-1. 
Tomova, I., Lazarkevich, I., Tomova, A., Kambourova, M., and VasilevaTonkova, E., 2013, Diversity and biosynthetic potential of culturable aerobic heterotrophic bacteria isolated from Magura Cave, Bulgaria: International Journal of Speleology, v. 42, no. 1, p. 65-76. doi:10.5038/ 1827-806X.42.1.8.

Trajano, E., and Bichuette, M. E., 2010, Diversity of Brazilian subterranean invertebrates, with a list of troglomorphic taxa: Subterranean Biology, v. 7, p. $1-16$.

Vance, E.D., Brookes, P.C., and Jenkinson, D.S., 1987, An extraction method for measuring soil microbial biomass C: Soil Biology and Biochemistry, v. 19, p. 703-707. doi:10.1016/0038-0717(87)90052-6.

Vanderwolf, K.J., Malloch, D., McAlpine, D.F., and Forbes, G.J., 2013, A world review of fungi, yeasts, and slime mold in caves: International Journal of Speleology, v. 42, no. 1, p. 77-96. doi:10.5038/1827-806X.42. 1.9 .

Walkey, A., and Black, I.A., 1934, An examination of the Degtjareff method for determining soil organic matter and a proposed modification of the chromic acid titration method: Soil Science, v. 37, p. 29-38.
Wang, Wanfu, Ma, Xu, Ma, Yantian, Mao, Lin, Wu, Fasi, Ma, Xiaojun, An, Lizhe, and Feng, Hayuan, 2010, Seasonal dynamics of airborne fungi in different caves of the Mogao Grottoes, Dunhuang, China: International Biodeterioration and Biodegradation, v. 64, p. 461-466, doi:10.1016/j. ibiod.2010.05.005.

Wollum II, A.G., 1982, Cultural methods for soil microorganisms, in Page, A.L., Miller, R.H., and Keeney, D.R., eds., Methods of Soil Analysis, Part 2: Chemical and Microbiological Properties, second edition: Madison, American Society of Agronomy and Soil Science Society of America, Agronomy series 9(2), p. 781-802. doi:10.2134/agronmonogr9. 2.2ed.c37.

Yoder, J.A., Benoit, J.B., Christensen, B.S., Croxall, T.J., and Hobbs III, H.H., 2009, Entomopathogenic fungi carried by the cave orb weaver spider, Meta ovalis (Araneae, Tetragnathidae), with implications for mycoflora transfer to cave crickets: Journal of Cave and Karst Studies, v. 71, no. 2, p. $116-120$. 